\title{
GENETIC STRUCTURE OF ANNUAL RYEGRASS (Lolium multiflorum) POPULATIONS ESTIMATED BY RAPD
}

\author{
Eduardo Alano Vieira ${ }^{1}$; Caroline Marques Castro²; Antônio Costa de Oliveira ${ }^{3 *}$; Fernando Irajá \\ Félix de Carvalho ${ }^{3}$; Paulo Dejalma Zimmer ${ }^{3}$; Luís Fernando Martins ${ }^{1}$ \\ ${ }^{1}$ UFPel/FAEM - Programa de Pós-Graduação em Agronomia/Fitomelhoramento. \\ ${ }^{2}$ Embrapa Clima Temperado, C.P. 403 - 96001-970 - Pelotas, RS - Brasil. \\ ${ }^{3}$ UFPel/FAEM - Depto. de Fitotecnia, C.P. 354 - 96010-900 - Pelotas, RS - Brasil. \\ *Corresponding author <acostol@terra.com.br>
}

\begin{abstract}
Annual ryegrass is a temperate climate annual foraging grass, grown mostly in the South of Brazil, especially in the state of Rio Grande do Sul. Despite its importance, little is known about its genetic diversity, both within and among the populations cultivated. This knowledge is of fundamental importance for developing breeding and conservation strategies. The aim of this study was to characterize the genetic diversity and structure of four populations of annual ryegrass. Three of the populations were located in Rio Grande do Sul and the fourth in Uruguay. RAPD markers were used to study the genetic diversity and structure of these populations. Analysis of 375 individuals sampled from the populations, using six RAPD primers, generated a total of 82 amplified bands. They included 73 polymorphic bands (89,02\%). The value of the total genetic diversity index obtained, $\overline{\mathrm{H}}_{\text {species }}(0,71)$ was high, indicating the presence of wide genetic diversity in the four populations. Genetic structure analysis revealed that $98 \%$ of total diversity is intrapopulational, whereas interpopulational genetic diversity was only $2 \%$. These results suggest that before these populations separated, they had gone through a period of gene exchange and, even after the separation event, gene frequency stayed at levels similar to the original levels, with no differential selection for these genes in the different cultivation areas.
\end{abstract}

Key words: foraging, genetic diversity, molecular markers

\section{ESTRUTURA GENÉTICA DE POPULAÇÕES DE AZEVÉM ANUAL (Lolium multiflorum) ESTIMADA POR RAPD}

\begin{abstract}
RESUMO: O azevém anual é a gramínea anual forrageira de clima temperado de maior utilização no sul do Brasil, particularmente no Estado do Rio Grande do Sul. Apesar de toda a importância que a espécie apresenta, pouco se conhece a respeito da diversidade genética presente entre e dentro das populações cultivadas. Este conhecimento é de fundamental importância para o estabelecimento das estratégias de melhoramento genético e de conservação destes materiais. O objetivo deste estudo foi caracterizar a diversidade genética e a estrutura genética de quatro populações de azevém anual, sendo três populações do Estado do Rio Grande do Sul e uma do Uruguai. O nível de diversidade e a estrutura genética destas populações foram estudados com marcadores RAPD. A análise de 375 indivíduos amostrados nas populações, com seis iniciadores, gerou um total de 82 bandas que foram utilizados nas análises, dentre as quais 73 (89,02\%) foram polimórficas. O valor do índice de diversidade genética total obtido, $\overline{\mathrm{H}}_{\text {species }}(0,71)$ foi elevado evidenciando a presença de uma grande diversidade genética nas quatro populações. A análise da estrutura genética revelou que $98 \%$ da diversidade total esta contida dentro das populações, enquanto que a diversidade genética entre as populações representou somente $2 \%$. Sugere-se que antes da separação destas populações, as mesmas tenham passado por um período de troca de genes e que mesmo após o evento de separação elas mantiveram a freqüência destes em níveis semelhantes aos originais, não tendo ocorrido uma seleção diferencial destes genes nos locais de cultivo.

Palavras-chave: forrageira, diversidade genética, marcadores moleculares
\end{abstract}

\section{INTRODUCTION}

Natural pasture accounts for $61 \%$ of the area of Rio Grande do Sul. This pasture consists mainly of species that grow in spring-summer, with a marked drop in productivity in the colder seasons (Mota et al., 1981). Among the temperate climate forage species, annual ryegrass (Lolium multiflorum) is the most widely used annual forage grass (Maia, 1995) because of its high productivity and palatability, excellent resprouting and easy plantability (Carambula, 1971).

The pasture incorporates more than 10,000 species, forming the most widely varied plant group in the world. However, by contrast with grain, its origins are difficult to pinpoint (Spedding \& Diekmahns, 1972). The main centre of diversity for the Festuceae tribe is East- 
ern Europe, where the genus Lolium is found (Borrill, 1986). The origins of annual ryegrass are still undefined, but we do know that this species was among the natural vegetation in the fields of northern Italy, where it probably originated (Spedding \& Diekmahns, 1972). In Brazil, foraging was introduced into Rio Grande do Sul by Italian immigrants in 1875 (Araújo, 1978).

Genetic improvement of this crop is important. This is why it is essential to get to know cultivated populations both in terms of genetic variability and access quality. When defining the breeding and conservation strategies to be put in place (Auler et al., 2002), we must know the degree of genetic diversity and genetic structure of the populations concerned.

Molecular marker techniques have produced valuable information in respect of the genetic structure and variability of populations of various species (Hamrick, 1990; Powell et al., 1995; 1996a; 1996b; Oliveira et al., 1996; Ouborg et al., 1999). Among the molecular marker techniques used, the Randomly Amplified Polymorphic DNA (RAPD) method stands out because it is fast and easy to use, and is relatively low-cost when compared to other molecular techniques (Cruz \& Milach, 1998).

RAPD markers offer extraordinary potential for investigating the genetic variability of forage species (Chai \& Sticklen, 1998). However, care must be taken with the type of sample. It is necessary to assess individual plants instead of bulk samples so as to guarantee the genotypical composition of a synthetic cultivar. This is because material originating from bulk samples, when amplified, results simply in the sum of the products originated by individual plants, and does not reflect all the inter- and intrapopulational diversity (Sweeney \& Danneberger, 1994).

The aim of this study was to characterize the genetic structure and diversity of four populations of annual ryegrass using RAPD markers. Three of the populations were located in Rio Grande do Sul and the fourth in Uruguay.

\section{MATERIALS AND METHODS}

\section{Vegetable material}

The study assessed four populations of annual ryegrass, three of which were traditional populations of the state of Rio Grande do Sul, collected in the municipal districts of Pantano Grande (Central region - $30^{\circ} 13^{\prime}$ 'S, $52^{\circ} 23^{\prime} \mathrm{W}$ ), Dom Pedrito (Western region -3059'S,

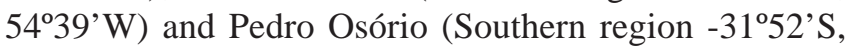
$52^{\circ} 49^{\prime} \mathrm{W}$ ). In the study, these populations are denoted B, $\mathrm{C}$ and $\mathrm{D}$, respectively. Collection locations were defined to satisfy the need to sample the three geographic regions of the State in which foraging was most common. The fourth population assessed was the Uruguaian cultivar "La
Estanzuela - 284", denoted population A. It was chosen because it is widely used, mainly in the Brazil/Uruguay frontier region ( $38^{\circ} 00^{\prime} \mathrm{S}, 57^{\circ} 00^{\prime} \mathrm{W}$ ). A total of 375 genotypes were assessed: 99 from population A, 84 from population B, 96 from population $\mathrm{C}$ and 96 from population D.

\section{DNA extraction and RAPD amplification reaction}

DNA was extracted from two independent leaf samples of each genotype, as in Yang et al. (1996), using the extraction method described by Saghai-Maroof et al. (1984). The DNA was quantified by electrophoresis in agarose gel $(0,8 \%)$ stained with ethydium bromide. The DNA concentration was estimated by comparison with the known standard for the molecular mass marker: Low DNA Mass Ladder (Invitrogen - Life Technologies).

Amplifications were carried out at a final volume of $25 \mu \mathrm{L}$ containing $25 \mathrm{ng}$ of genomic DNA, 0.2 mmol L ${ }^{-1}$ of dNTPs, $0.2 \mathrm{mmol} \mathrm{L}^{-1}$ of cresol red stain, $0.5 \mathrm{mmol} \mathrm{L}^{-1}$ of primer, $2.5 \mathrm{mmol} \mathrm{L}{ }^{-1}$ of $\mathrm{MgCl}_{2}, 50 \mathrm{mmol}$ $\mathrm{L}^{-1}$ of $\mathrm{KCl}, 10 \mathrm{mmol} \mathrm{L}^{-1}$ of Tris-HCl (pH 8.0), $0.1 \%$ (v/ v) of Triton $\mathrm{x}-100$ and 1.5 units of Taq polimerase (Invitrogen). PCR reactions were carried out in a thermocycler (MJ Research PTC-100) programmed for an initial denaturing step at $94^{\circ} \mathrm{C}$ for 3 minutes, followed by 44 cycles of 1 minute at $94^{\circ} \mathrm{C}, 1$ minute at $38^{\circ} \mathrm{C}$ and 1.5 minutes at $72^{\circ} \mathrm{C}$. The reaction was completed by a final step of 5 minutes at $72^{\circ} \mathrm{C}$. The amplified fragments were separated by electrophoresis in agarose gel (1.4\%), stained with ethydium bromide and photographed using a UV transluminator.

During the work, we used six primers supplied by the University of British Columbia (UBC): i) UBC2CCTGGGCTTC; ii) UBC3- CCTGGGCTTA; iii) UBC4CCTGGGCTGG; iv) UBC9- CCTGCGCTTA; v) UBC12- CCTGGGTCCA e vi) UBC13CCTGGGTGGA.

\section{Data analysis and genetic diversity estimates}

Products of the amplification reactions consistent for two independent extractions were classified according to presence (1) or absence (0) of bands. Genetic diversity was measured using the Shannon-Wiener function: $\mathrm{H}^{\prime}=-\sum \mathrm{P}_{\mathrm{i}} \log _{2}\left(\mathrm{P}_{\mathrm{i}}\right)$, where $\mathrm{P}_{\mathrm{i}}$ is the frequency of class $\mathrm{i}$ (presence or absence of band $\mathrm{i}$ ), according to the methodology proposed by Lewontin (1972). This methodology was used because it is suitable for analysing binary data (presence $v$. absence of band) obtained using dominant markers such as RAPD. A similar method was used for estimating genetic diversity in vegetable species (Yun et al., 1998; Whitkus et al., 1998; Aga et al., 2003; Fu et al., 2003).

First, the indexes were computed for diversity within the populations: i) $\mathrm{H}_{0}$ (genetic diversity of each marker in each population) based on the presence/absence 
frequency of each marker in each population; ii) $\mathrm{H}_{\text {pop }}$ (average genetic diversity of each marker in the four populations) using the arithmetic average of the $\mathrm{H}_{0}$ of each marker in the four populations, and iii) $\overline{\mathrm{H}}_{\text {pop }}$ (genetic diversity within the populations) using the arithmetic average of the $\mathrm{H}_{\text {pop }}$ of all markers studied. Then the interpopulation indexes were computed: i) $\mathrm{H}_{\text {species }}$ (genetic diversity of each marker in the four populations) based on the presence/absence frequency of each marker in the four populations, and ii) $\overline{\mathrm{H}}_{\text {species }}$ (total genetic diversity) using the arithmetic average of the $\mathrm{H}_{\text {species }}$ of all markers studied.

We then computed the proportion of genetic diversity within the populations for each marker analysed $\left(\mathrm{H}_{\text {pop }} / \mathrm{H}_{\text {species }}\right)$ and in all markers studied ( $\left.\overline{\mathrm{H}}_{\text {pop }} / \overline{\mathrm{H}}_{\text {species }}\right)$, together with the proportion of genetic diversity present between the populations for each marker studied $\left(\mathrm{H}_{\text {species }}\right.$ $\left.-\mathrm{H}_{\text {pop }}\right) / \mathrm{H}_{\text {species }}$ and for all markers $\left(\overline{\mathrm{H}}_{\text {species }}-\overline{\mathrm{H}}_{\text {pop }}\right) \overline{\mathrm{H}}_{\text {species }}$.

Band presence/absence data obtained by RAPD analysis of 60 individuals taken at random (15 from each population) were used to compute the genetic similarity of all pairs of individuals sampled, using the NTSYS program (Rohlf, 2000). The Dice coefficient (Dice, 1945) was used to compute genetic similarity and, based on the similarity matrix produced, we constructed a dendrogram using the UPGMA grouping method. To check the adjust- ment between the similarity matrix and the dendrogram obtained, we computed the cophenetic correlation coefficient (r) in accordance with Sokal \& Rohlf (1962). The statistical stability of the groupings was estimated by bootstrap analysis with 100 replicates, using Winboot (Yap \& Nelson, 1996).

\section{RESULTS AND DISCUSSION}

The six primers used in this study produced a total of 82 RAPD bands in the 375 sampled individuals, 73 of which (89.02\%) were polymorphic. Of these, only band UBC12-09 was polymorphic in population D; bands UBC12-10 and UBC12-12 were not polymorphic in population $\mathrm{C}$ and band UBC12-11 was not polymorphic in populations $\mathrm{B}$ and $\mathrm{C}$ (Table 1 ).

Primers UBC04, UBC13, UBC03 and UBC12 detected most of the polymorphic bands (16, 15, 14 and 12 bands, respectively), whereas primers UBC02 and UBC09 revealed 9 and 7 polymorphic bands, respectively (Table 1). The degree of polymorphism detected was fairly high, showing that the RAPD markers were efficient in detecting genetic variability between the individuals studied. Sweeney et al. (1996) have already reported on the efficiency of RAPD markers in identifying the cultivars of foraging species.

Table 1 - Estimates of $\mathrm{H}_{0}$ (genetic diversity of each marker in each population), $\mathrm{H}_{\text {pop }}$ (average genetic diversity of each marker in the four populations), $\mathrm{H}_{\text {species }}$ (genetic diversity of each marker in the four populations), $\mathrm{H}_{\text {pop }} / \mathrm{H}_{\text {species }}$ (proportion of intrapopulational genetic diversity for each marker), $\left(\mathrm{H}_{\text {species }}-\mathrm{H}_{\text {pop }}\right) / \mathrm{H}_{\text {species }}$ (proportion of interpopulational genetic diversity for each marker).

\begin{tabular}{|c|c|c|c|c|c|c|c|c|}
\hline \multirow{3}{*}{ Primer/marker } & & & & & \multirow{3}{*}{$\mathrm{H}_{\mathrm{pop}}$} & \multirow{3}{*}{$\mathrm{H}_{\text {species }}$} & \multirow{3}{*}{$\begin{array}{c}\mathrm{H}_{\text {pop }} \\
\mathrm{H}_{\text {species }} \\
\end{array}$} & \multirow{3}{*}{$\begin{array}{c}\mathrm{H}_{\text {species }}-\mathrm{H}_{\text {pop }} \\
\mathrm{H}_{\text {species }}\end{array}$} \\
\hline & \multicolumn{4}{|c|}{$\mathrm{H}_{0}$} & & & & \\
\hline & Pop. A & Pop. B & Pop. C & Pop. D & & & & \\
\hline UBC $02-01$ & 0.95 & 0.99 & 0.99 & 0.99 & 0.98 & 0.99 & 0.99 & 0.01 \\
\hline UBC $02-02$ & 0.56 & 0.65 & 0.79 & 0.79 & 0.70 & 0.71 & 0.98 & 0.02 \\
\hline UBC $02-03$ & 0.76 & 0.73 & 0.92 & 0.95 & 0.84 & 0.86 & 0.97 & 0.03 \\
\hline UBC $02-04$ & 0.76 & 0.59 & 0.67 & 0.51 & 0.64 & 0.65 & 0.98 & 0.02 \\
\hline UBC $02-05$ & 0.96 & 0.95 & 0.95 & 0.70 & 0.89 & 0.91 & 0.98 & 0.02 \\
\hline UBC $02-06$ & 0.95 & 1.00 & 0.98 & 0.95 & 0.97 & 1.00 & 0.97 & 0.03 \\
\hline UBC $02-07$ & 0.99 & 0.97 & 0.92 & 0.88 & 0.94 & 0.97 & 0.97 & 0.03 \\
\hline UBC $02-08$ & 0.97 & 0.99 & 1.00 & 0.95 & 0.98 & 1.00 & 0.98 & 0.02 \\
\hline UBC $02-09$ & 0.73 & 0.85 & 0.60 & 0.54 & 0.68 & 0.69 & 0.99 & 0.01 \\
\hline UBC $03-01$ & 0.75 & 0.49 & 0.76 & 0.60 & 0.65 & 0.67 & 0.97 & 0.03 \\
\hline UBC $03-02$ & 0.80 & 0.83 & 0.94 & 0.76 & 0.83 & 0.84 & 0.99 & 0.01 \\
\hline UBC $03-03$ & 0.24 & 0.37 & 0.57 & 0.70 & 0.47 & 0.50 & 0.95 & 0.05 \\
\hline UBC $03-04$ & 0.56 & 0.62 & 0.72 & 0.76 & 0.66 & 0.67 & 0.99 & 0.01 \\
\hline UBC $03-05$ & 0.95 & 0.99 & 1.00 & 0.99 & 0.98 & 0.99 & 0.99 & 0.01 \\
\hline UBC $03-06$ & 1.00 & 0.99 & 0.99 & 0.99 & 0.99 & 0.99 & 1.00 & 0.00 \\
\hline UBC $03-07$ & 0.76 & 0.83 & 0.96 & 0.72 & 0.82 & 0.84 & 0.98 & 0.02 \\
\hline UBC $03-08$ & 0.88 & 0.86 & 0.95 & 0.91 & 0.90 & 0.90 & 1.00 & 0.00 \\
\hline UBC $03-09$ & 0.75 & 0.88 & 0.98 & 0.97 & 0.89 & 0.92 & 0.97 & 0.03 \\
\hline UBC $03-10$ & 1.00 & 0.99 & 0.99 & 0.98 & 0.99 & 1.00 & 0.99 & 0.01 \\
\hline UBC $03-11$ & 1.00 & 0.93 & 1.00 & 0.93 & 0.96 & 0.98 & 0.98 & 0.02 \\
\hline UBC $03-12$ & 0.98 & 0.91 & 0.98 & 0.90 & 0.94 & 0.99 & 0.95 & 0.05 \\
\hline
\end{tabular}


Table 1 - Continuation.

\begin{tabular}{|c|c|c|c|c|c|c|c|c|}
\hline UBC $03-13$ & 0.47 & 0.70 & 0.20 & 0.15 & 0.38 & 0.41 & 0.92 & 0.08 \\
\hline UBC $03-14$ & 0.50 & 0.41 & 0.41 & 0.25 & 0.40 & 0.40 & 0.98 & 0.02 \\
\hline UBC 03 - 15 & 0.00 & 0.00 & 0.00 & 0.00 & 0.00 & 0.00 & 0.00 & 0.00 \\
\hline UBC $03-16^{\mathrm{T}}$ & 0.00 & 0.00 & 0.00 & 0.00 & 0.00 & 0.00 & 0.00 & 0.00 \\
\hline UBC $04-01$ & 0.80 & 0.75 & 0.60 & 0.54 & 0.67 & 0.68 & 0.99 & 0.01 \\
\hline UBC $04-02$ & 1.00 & 0.97 & 0.83 & 0.78 & 0.89 & 0.94 & 0.96 & 0.04 \\
\hline UBC $04-03$ & 0.56 & 0.70 & 0.67 & 0.65 & 0.65 & 0.65 & 1.00 & 0.00 \\
\hline UBC $04-04$ & 0.93 & 0.96 & 0.78 & 0.84 & 0.88 & 0.89 & 0.99 & 0.01 \\
\hline UBC $04-05$ & 0.66 & 0.70 & 0.65 & 0.78 & 0.70 & 0.70 & 1.00 & 0.00 \\
\hline UBC $04-06$ & 0.88 & 0.79 & 0.90 & 0.93 & 0.88 & 0.88 & 0.99 & 0.01 \\
\hline UBC $04-07$ & 0.94 & 0.85 & 0.76 & 0.96 & 0.88 & 0.89 & 0.98 & 0.02 \\
\hline UBC $04-08$ & 0.87 & 0.93 & 0.86 & 0.93 & 0.90 & 0.90 & 1.00 & 0.00 \\
\hline UBC $04-09$ & 0.97 & 0.99 & 0.91 & 0.95 & 0.95 & 0.96 & 1.00 & 0.00 \\
\hline UBC $04-10$ & 0.93 & 1.00 & 0.97 & 0.95 & 0.96 & 0.97 & 0.99 & 0.01 \\
\hline UBC $04-11$ & 1.00 & 0.99 & 0.97 & 0.96 & 0.98 & 0.99 & 0.99 & 0.01 \\
\hline UBC $04-12$ & 1.00 & 1.00 & 0.99 & 0.98 & 0.99 & 1.00 & 1.00 & 0.00 \\
\hline UBC $04-13$ & 0.95 & 0.89 & 0.95 & 0.91 & 0.93 & 0.93 & 1.00 & 0.00 \\
\hline UBC $04-14$ & 0.80 & 0.97 & 1.00 & 0.96 & 0.93 & 0.96 & 0.98 & 0.02 \\
\hline UBC $04-15$ & 0.78 & 0.94 & 0.98 & 0.86 & 0.89 & 0.91 & 0.98 & 0.02 \\
\hline UBC $04-16$ & 0.88 & 0.85 & 0.95 & 0.72 & 0.85 & 0.87 & 0.98 & 0.02 \\
\hline UBC $09-01$ & 0.14 & 0.22 & 0.38 & 0.63 & 0.34 & 0.37 & 0.92 & 0.08 \\
\hline UBC $09-02$ & 0.99 & 1.00 & 0.98 & 0.98 & 0.99 & 0.99 & 1.00 & 0.00 \\
\hline UBC $09-03$ & 0.29 & 0.22 & 0.48 & 0.65 & 0.41 & 0.44 & 0.94 & 0.06 \\
\hline UBC $09-04$ & 0.20 & 0.16 & 0.41 & 0.63 & 0.35 & 0.38 & 0.91 & 0.09 \\
\hline UBC $09-05$ & 0.99 & 0.99 & 0.86 & 1.00 & 0.96 & 0.99 & 0.97 & 0.03 \\
\hline UBC $09-06$ & 0.91 & 0.83 & 0.54 & 0.67 & 0.74 & 0.76 & 0.97 & 0.03 \\
\hline UBC $09-07$ & 0.20 & 0.09 & 0.08 & 0.08 & 0.11 & 0.12 & 0.96 & 0.04 \\
\hline UBC $09-08^{\mathrm{T}}$ & 0.00 & 0.00 & 0.00 & 0.00 & 0.00 & 0.00 & 0.00 & 0.00 \\
\hline UBC $09-09^{\mathrm{T}}$ & 0.00 & 0.00 & 0.00 & 0.00 & 0.00 & 0.00 & 0.00 & 0.00 \\
\hline UBC $09-10^{\mathrm{T}}$ & 0.00 & 0.00 & 0.00 & 0.00 & 0.00 & 0.00 & 0.00 & 0.00 \\
\hline UBC $09-11^{\mathrm{T}}$ & 0.00 & 0.00 & 0.00 & 0.00 & 0.00 & 0.00 & 0.00 & 0.00 \\
\hline UBC $12-01$ & 0.75 & 0.75 & 0.65 & 0.63 & 0.69 & 0.69 & 1.00 & 0.00 \\
\hline UBC $12-02$ & 0.85 & 0.88 & 0.84 & 0.74 & 0.83 & 0.83 & 1.00 & 0.00 \\
\hline UBC $12-03$ & 0.71 & 0.70 & 0.83 & 0.92 & 0.79 & 0.80 & 0.98 & 0.02 \\
\hline UBC $12-04$ & 0.29 & 0.49 & 0.57 & 0.74 & 0.52 & 0.54 & 0.96 & 0.04 \\
\hline UBC $12-05$ & 0.56 & 0.65 & 0.65 & 0.91 & 0.69 & 0.72 & 0.97 & 0.03 \\
\hline UBC $12-06$ & 0.98 & 0.92 & 0.99 & 0.98 & 0.97 & 0.98 & 0.99 & 0.01 \\
\hline UBC $12-07$ & 0.68 & 0.77 & 0.63 & 0.87 & 0.74 & 0.75 & 0.99 & 0.01 \\
\hline UBC $12-08$ & 1.00 & 1.00 & 0.99 & 0.97 & 0.99 & 1.00 & 0.99 & 0.01 \\
\hline UBC $12-09$ & 0.00 & 0.00 & 0.00 & 0.51 & 0.13 & 0.19 & 0.67 & 0.33 \\
\hline UBC $12-10$ & 0.08 & 0.16 & 0.00 & 0.57 & 0.20 & 0.25 & 0.80 & 0.20 \\
\hline UBC $12-11$ & 0.08 & 0.00 & 0.00 & 0.60 & 0.17 & 0.24 & 0.70 & 0.30 \\
\hline UBC $12-12$ & 0.08 & 0.16 & 0.00 & 0.57 & 0.20 & 0.25 & 0.80 & 0.20 \\
\hline UBC $12-13^{\mathrm{T}}$ & 0.00 & 0.00 & 0.00 & 0.00 & 0.00 & 0.00 & 0.00 & 0.00 \\
\hline UBC $12-14^{\mathrm{T}}$ & 0.00 & 0.00 & 0.00 & 0.00 & 0.00 & 0.00 & 0.00 & 0.00 \\
\hline UBC $12-15^{\mathrm{T}}$ & 0.00 & 0.00 & 0.00 & 0.00 & 0.00 & 0.00 & 0.00 & 0.00 \\
\hline UBC $13-01$ & 1.00 & 1.00 & 0.98 & 1.00 & 0.99 & 1.00 & 0.99 & 0.01 \\
\hline UBC $13-02$ & 0.68 & 0.73 & 0.84 & 0.84 & 0.77 & 0.78 & 0.99 & 0.01 \\
\hline UBC $13-03$ & 0.64 & 0.70 & 0.81 & 0.74 & 0.72 & 0.73 & 0.99 & 0.01 \\
\hline UBC $13-04$ & 0.99 & 0.97 & 0.96 & 0.83 & 0.94 & 0.95 & 0.98 & 0.02 \\
\hline UBC $13-05$ & 0.88 & 0.93 & 0.91 & 1.00 & 0.93 & 0.95 & 0.98 & 0.02 \\
\hline UBC $13-06$ & 0.98 & 0.93 & 0.81 & 0.98 & 0.93 & 0.94 & 0.98 & 0.02 \\
\hline UBC $13-07$ & 0.94 & 0.96 & 0.97 & 0.90 & 0.94 & 0.94 & 1.00 & 0.00 \\
\hline UBC $13-08$ & 0.91 & 0.97 & 0.95 & 0.91 & 0.93 & 0.94 & 1.00 & 0.00 \\
\hline UBC 13 - 09 & 1.00 & 1.00 & 0.97 & 1.00 & 0.99 & 1.00 & 0.99 & 0.01 \\
\hline UBC $13-10$ & 0.99 & 0.98 & 1.00 & 0.99 & 0.99 & 1.00 & 0.99 & 0.01 \\
\hline UBC 13 - 11 & 0.95 & 0.97 & 0.98 & 0.99 & 0.97 & 0.98 & 1.00 & 0.00 \\
\hline UBC $13-12$ & 0.92 & 0.95 & 0.94 & 0.98 & 0.95 & 0.95 & 1.00 & 0.00 \\
\hline UBC $13-13$ & 0.98 & 0.99 & 1.00 & 0.97 & 0.99 & 1.00 & 0.99 & 0.01 \\
\hline UBC $13-14$ & 0.98 & 0.97 & 0.99 & 0.81 & 0.94 & 0.98 & 0.96 & 0.04 \\
\hline UBC 13 - 15 & 0.95 & 0.99 & 0.94 & 0.78 & 0.91 & 0.93 & 0.98 & 0.02 \\
\hline
\end{tabular}

${ }^{\Theta}$ monomorphic markers 
The genetic diversity figures for the markers detected in the different populations $\left(\mathrm{H}_{0}\right)$ varied between a minimum of 0.08 and a maximum of 1.00 , in the polymorphic markes (Table 1). In the majority of markers, values of $\mathrm{H}_{0}$ were fairly high (0.9 or higher in $49 \%$ of cases), revealing the existence of high genetic diversity in the populations studied and showing that the frequency of the markers detected (band presence) is close to 0.5 for the majority of markers assessed. Contrasting results were obtained by Kubik et al. (2001) using microsatellite markers in seven cultivars of perennial ryegrass, with values of $\mathrm{H}_{0}$ varying from 0.58 to 0.63 . This discrepancy in the values obtained can be explained in terms of the species' life cycles which are very different (annual as opposed to perennial), and by the different methodology used for computing $\mathrm{H}_{0}$.

The results obtained for the genetic diversity of each marker within the populations $\left(\mathrm{H}_{\mathrm{pop}}\right)$, computed on the basis of the average genetic diversity of each marker in the four populations, varied from a minimum of 0.11 to a maximum of 0.99 in the polymorphic markers. In addition, $\mathrm{H}_{\text {pop }}$ was high in the majority of markers, being 0.9 or higher in $48 \%$ of cases (Table 1 ).

The total genetic diversity of each marker $\left(\mathrm{H}_{\text {species }}\right)$ was also high in most of the amplified fragments, and when the four populations are taken as a whole, the frequencies of the markers detected are close to 0.5 for the majority of markers. These figures varied from a minimum of 0.12 to a maximum of 1.00 for polymorphic markers, and were 0.9 or higher for $52 \%$ of the markers assessed.

Individual analysis of each marker showed that most genetic diversity is confined within the populations: i.e., for $88 \%$ of markers, less than $5 \%$ genetic diversity is present among the four ryegrass populations studied (Table 1). The markers that showed the most genetic diversity among the populations $\left(\mathrm{H}_{\text {species }}-\mathrm{H}_{\text {pop }} / \mathrm{H}_{\text {species }}\right)$ were UBC12 (09, 10, 11 and 12), which were not polymorphic in all sampled populations, and thus revealed genetic differences among the populations of 33, 20, 30 and $20 \%$, respectively (Table 1 ).

Monomorphic markers for some populations and polymorphic for others, as mentioned above, could constitute markers with potential for populational differentiation. In addition, there is the possibility of associating these markers with adaptive characteristics which could be influenced by the different environments in which the populations are cultivated. The use of markers UBC12 09, 10, 11 and 12 in future studies could facilitate the production of probes or primers with adaptive characteristics advantageous to the agrobusiness sector, marking contrasts between populations and segregating in the one or more populations in which they are polymorphic.

Table 2 shows average diversity indexes taking all 82 markers together. The total genetic diversity fig- ure $\overline{\mathrm{H}}_{\text {species }}$ was fairly high (0.71) and is very close to the estimated value for genetic diversity within populations $\left(\overline{\mathrm{H}}_{\mathrm{pop}}\right)$ of 0.70 , showing that the ryegrass populations present high diversity indexes, that a large part of this diversity is conserved with populations and that little interpopulation genetic diversity is present, since only $2.0 \%$ of the total variation is distributed among the populations studied (Table 2). This can be explained by the fact that ryegrass is a cross-pollenating plant with gametophytic self-incompatibility, and by the fact that these populations are confined in large cultivation areas, reducing the possibility of genetic drift and inbreeding, and thus conserving the high genetic diversity of the populations. This high diversity (within populations) could also be explained by the relatively short period of cultivation and artificial selection of forage species, which has not yet allowed ample population differentiation (Breese \& Hayward, 1972).

This difficulty in separating populations was also encountered in genetic diversity studies on populations of various alogamous forage species, such as: Lolium perenne L. (Huff, 1997; Kubik et al., 2001), Chloris gayana K. (Ubi et al., 2003), Pascopryum smithii (Larson et al., 2003) and different species of genus Lolium: (Cresswell et al., 2001). High genetic diversity within populations is consistent with results reported for other alogamous species (Cardoso et al., 2000; Cabral et al., 2002).

The dendrogram indicated that there was no differentiation between genotypes according to origin, revealing a large number of superimpositions across the populations studied (Figure 1). Only one of the groups formed presented a high bootstrapping figure (86\%), and this group is formed for all genotypes (except two in population D), which also backs up the evidence in favour of little genetic differentiation between sampled populations. The cophenetic correlation coefficient (r) of 0.84 shows that the adjustment is correct between the similarity matrix and the dendrogram obtained.
Tabela 2 - Estimates of ${ }^{\mathrm{a}} \overline{\mathrm{H}}_{\text {pop }},{ }^{\mathrm{b}} \overline{\mathrm{H}}_{\text {species }},{ }^{\mathrm{c}} \overline{\mathrm{H}}_{\text {pop }} / \overline{\mathrm{H}}_{\text {species }},{ }^{\mathrm{d}}\left(\overline{\mathrm{H}}_{\text {species }}\right.$ - $\left.\overline{\mathrm{H}}_{\text {pop }}\right) / \overline{\mathrm{H}}_{\text {species }}$.

\begin{tabular}{lc}
\hline Parameter & Estimate \\
\hline $\mathrm{H}_{\text {pop }}$ & 0.70 \\
\hline $\mathrm{H}_{\text {species }}$ & 0.71 \\
$\overline{\mathrm{H}}_{\text {pop }} / \overline{\mathrm{H}}_{\text {species }}$ & 0.98 \\
$\left(\overline{\mathrm{H}}_{\text {species }}-\overline{\mathrm{H}}_{\text {pop }}\right) / \overline{\mathrm{H}}_{\text {species }}$ & 0.02
\end{tabular}

aintrapopulational genetic diversity; ${ }^{b}$ total genetic diversity; cproportion of intrapopulational genetic diversity; dproportion of interpopulation genetic diversity. 


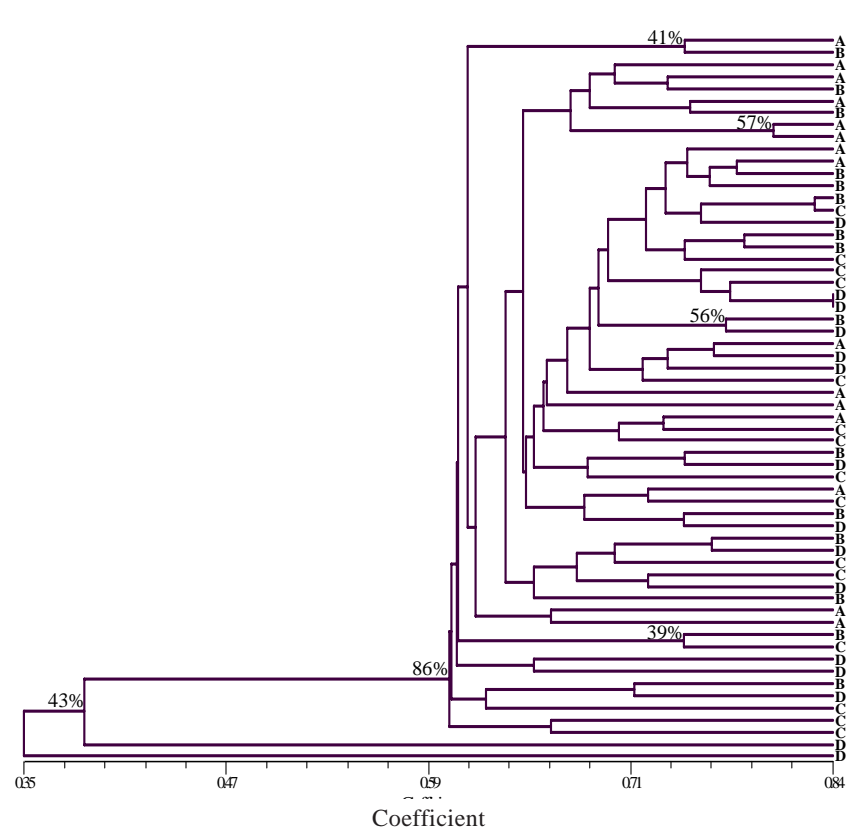

Figure 1 - Dendrogram of 60 individuals sampled at random in the four ryegrass populations (A, B, C e D), derived from RAPD analysis using the Dice similarity index (1945) and the UPGMA grouping method. Values in \% indicate the number of times genotypes grouped together in 100 cycles of bootstrapping using the Winboot software. The cophenetic correlation coefficient (r) is 0.84 .

Analysis of the genetic structure and similarity of the populations suggests that before separation, they had gone through a period of gene exchange and that even after the separation event, gene frequency stayed at levels similar to the original levels, with no differential selection for these genes in the different cultivation areas. However, care is required with this type of generalisation since the study covers only the variations detected by RAPD markers which can be of the non-adaptive type, not subject to selection in differing environments, and hence not differentiating the populations being studied.

In another study, these populations were analysed in terms of morphological characteristics, number of shoots, soil coverage, cycle, leaf area, number of leaves, average leaf area, dry leaf weight, dry stem weight, total dry weight and leaf: stem ratio (Castro et al., 2003). Of these characteristics, only the number of shoots and the cycle differentiated the four populations, and soil coverage was different for population B.

Thus, low interpopulation genetic diversity is consistent with high morphological similarity between individuals, suggesting that the selection process implemented, rather than being a conscious effort, was the result of mechanized seed collection, so that the populations became differentiated in terms of cycle and the number of shoots. In this way, as also observed by Castro et al. (2003), the population with the most divergent individuals, in both morphological and molecular terms, was population D (Figure 1), showing that this population, although no different in terms of genetic diversity from the other populations, contained some very contrasting individuals. This could provide a starting point for the selection of new populations.

\section{ACKNOWLEDGEMENTS}

To FAPERGS, CNPq and CAPES for help received, and grants for post-graduation and research productivity.

\section{REFERENCES}

AGA, E.; BRYNGELSSON, T.; BEKELE, E.; SALOMON, B. Genetic diversity of forest Arabica coffee (Coffea Arabica L.) in Ethiopia as revealed by random amplified polymorphic DNA (RAPD) analysis. Hereditas, v.138, p.36-46, 2003.

ARAÚJO, A.A. Forrageiras para ceifa: capineiras, fenação e ensilagem. Porto Alegre: Sulina, 1978. 169p.

AULER, N.M.F.; REIS, M.S.; GUERRA, M.P.; NODARI, R.O. The genetics and conservation of Araucaria angustifolia: I. Genetic structure and diversity of natural populations by means of non-adaptative variation in the state of Santa Catarina, Brazil. Genetics and Molecular Biology, v.25, p.329-338, 2002.

BORRILL, M. Temperate grasses. In: SIMMONDS, N. (Ed.) Evolution of crop plants. London: Logman, 1986. p.137-142.

BREESE, E.L.; HAYWARD, M.D. The genetic basis of present breeding methods in forage crops. Euphytica, v.21, p.324-336, 1972.

CABRAL, B.L.R.; SOUZA, J.A.de.; ANDO, A.; VEASEY, E.A.; CARDOSO, E.M.R. Isoenzymatic variability in cassava accessions from different regions in Brazil. Scientia Agricola, v.59, p.521-527, 2002.

CARAmbUla, M. Producción y manejo de pasturas sembradas. Montevideo: Hemisfério Sur, 1971. 463p.

CARDOSO, S.R.S.; ELOY, N.B.; PROVAN, J.; CARDOSO, M.A.; FERREIRA, P.C.G. Genetic differentiation of Euterpe edulis Mart. populations estimated by AFLP analysis. Molecular Ecology, v.9, p.1753-1760, 2000.

CASTRO, C.M.; OLIVEIRA, A.C. de.; CARVALHO, F.I.F. de.; MAIA, M. de. S.; MATTOS, L.A.; FREITAS, F. Morphological and molecular characterization of Italian ryegrass populations. Crop Breeding and Applied Biotechnology, v.3, p.245-254, 2003.

CHAI, B.; STICKLEN, M.B. Applications of biotechnology in turf grass genetic improvement. Crop Science, v.38, p.1320-1338, 1998.

CRESSWELL, A.; HAMILTON, N.R.S.; ROY, A.K.; VIEGAS, M.F. Use of amplified fragment length polymorphism markers to assess genetic diversity in Lolium species from Portugal. Molecular Ecology, v.10, p.229-241, 2001.

CRUZ, R.P.; MILACH, S.C.K. Análise de RAPD. In: MILACH, S.C.K. (Ed.) Marcadores moleculares em plantas. Porto Alegre: Universidade Federal do Rio Grande do Sul, 1998. p.107-116.

DICE, L.R. Measures of the amount of ecological association between species. Ecology, v.26, p.297-307, 1945.

FU, C.; QIU, Y.; KONG, H. RAPD analysis for genetic diversity in Changium myrnioides. Botanical Bulletin of Academia Sinica, v.44, p.13-18, 2003.

HAMRICK, J.L. Isozymes and the analysis of genetic structure in plant populations. In: SOLTIS, E.D.; SOLTIS, O.S. (Ed.) Isozymes in plant biology. London: Chapman \& Hall, 1990. p.87-105.

HUFF, D.R. RAPD characterization of heterogeneous perennial ryegrass cultivars. Crop Science, v.37, p.557-564, 1997.

KUBIK, C.; SAWKINS, M.; MEYER, W.A.; GAUT, B.S. Genetic diversity in seven perennial ryegrass (Lolium perenne L.) cultivars based on SSR markers. Crop Science, v.41, p.1565-1572, 2001.

LARSON, S.R.; PALAZZO, A.J.; JENSEN, K.B. Identification of western wheatgrass cultivars and accessions by DNA fingerprinting and geographic provenance. Crop Science, v.43, p.394-401, 2003.

LEWONTIN, R.C. The apportionment of human diversity. Evolutionary Biology, v.6, p.381-398, 1972. 
MAIA, M.S. Secagem de sementes de azevém anual (Lolium moltiflorum Lam.) com ar em ambiente controlado. Pelotas, 1995. 108p. (Tese Doutorado) - Faculdade de Agronomia “Eliseu Maciel”, Universidade Federal de Pelotas.

MOTA, F.S.; BERNY, Z.B.; MOTA, J.F.A.S. Índice climático de crescimento de pastagens naturais no Rio Grande do Sul. Pesquisa Agropecuária Brasileira, v.16, p.453-472, 1981.

OLIVEIRA, A.C. de.; RICHTER, T.; BENNETZEN, J.L. Regional and racial specificities in sorghum germplasm assessed with DNA markers. Genome, v.39, p.579-587, 1996.

OUBORG, N.J.; PIQUOT, Y.; van GRONENDAEL, J.M. Population genetics, molecular markers and the study of dispersal in plants. Journal of Ecology, v.87, p.551-568, 1999.

POWEL, W.; MACHRAY, G.C.; PROVAN, J. Polymorphism revealed by simple sequence repeats. Trends in Plant Science, v.1, p.215-222, 1996a.

POWEL, W.; MORGANTE, M.; ANDRE, C.; HANAFEY, M.; VOGEL, J.; TINGEY, S.; RAFALSKI, A. The comparison of RFLP, RAPD, AFLP and SSR (microsatellite) markers for germplasm analysis. Molecular Breeding, v.2, p.225-238, 1996b.

POWEL, W.; OROZCO-CASTILLO, C.; CHALMERS, K.; PROVAN, J.; WAUGH, R. Polymerase chain reaction-based assays for the characterization of plant genetic resources. Electrophoresis, v.16, p.1726-1730, 1995.

ROHLF, F.J. NTSYS-pc Numerical taxonomy and multivariate analysis system. New York: Exeter Publishing Co, 2000.

SAGHAI-MAROOF, M.A.; SOLIMAN, K.M.; JORGENSEN, R.A.; ALLARD, R.W. Ribosomal DNA spacer length polymorphism in barley: Mendelian inheritance, chromosome location and population dynamics. Proceedings of the National Academy of Sciences of the USA., v.89, p.1477-1481, 1984.

SOKAL, R.R.; ROHLF, F.J. The comparison of dendrograms by objective methods. Taxon, v.11, p.30-40, 1962.
SPEDDING, C.R.W.; DIEKMAHNS, E.C. Grasses and legumes in British agriculture. Bucks: CAB, 1972. 250p.

SWEENEY, P.M.; DANNEBERGER, T.K. Random amplified polymorphic DNA in perennial ryegrass: A comparison of bulk samples vs. Individuals. HortScience, v.29, p.624-626, 1994.

SWEENEY, P.M.; GOLEMBIEWSKI, R.; DANNEBERGER, T.K. Random amplified polymorphic DNA analysis of dry turf grass seed. HortScience, v.31, p.400-401, 1996.

UBI, B.E.; KÜLLIKER, R.; FUGIMORI, M.; KOMATSU, T. Genetic diversity in diploid cultivars of rhodes grass determined on basis of amplified fragment length polymorphism markers. Crop Science, v.43, p.1516-1522, 2003.

YANG, W.; OLIVEIRA, A.C. de.; GODWIN, I.; SCHERTZ, K.; BENNETZEN, L. Comparison of DNA marker technologies in characterizing plant genome diversity: variability in Chinese sorghums. Crop Science, v.36, p.1669-1676, 1996.

YAP, I.V.; NELSON, R.J. Winboot: a program for performing bootstrap analysis of binary data to determine the confidence limits of UPGMAbased dendrograms. Manila: IRRI, 1996. 22p.

YUN, R.; ZHONG, M.; WANG, H.X.; WEI, W.; HU, Z.A.; QIAN, Y.Q. Study on DNA diversity of Liaodong populations at Dongling mountain region. Acta Botanica Sinica, v.40, p.169-175, 1998.

WHITKUS, R.; CRUZ, M.D.L.; MOTA-BRAVO, L.; GOMEZ-POMPA, A. Genetic diversity and relationships of cacao (Theobroma cacao L.) in southern Mexico. Theoretical and Applied Genetics, v.96, p.621627, 1998.

Received July 31, 2003

Accepted April 28, 2004 